\title{
GREEN LOGISTICS FOR SUSTAINABILITY
}

\author{
Assoc. Prof. Sevgi TÜZÜN RAD \\ Mersin University, FEAS, Mersin, Turkey (srad@mersin.edu.tr) \\ Ph.D. Student Yavuz Selim GÜLMEZ* \\ Gaziosmanpaşa University, FEAS, Tokat, Turkey (ysgulmez1@gmail.com)
}

\begin{abstract}
Sustainability is emerging as a salient concept with increasing importance. Since logistics is a core element in enterprise activities, sustainability is becoming a strategic issue for the logistics sector. Sustainability of enterprises is only possible if they are sustainable in terms of their natural, economic and social dimensions. In fact, environmental impacts of logistic practices are now included in "Logistic Performance Index" (LPI) developed by World Bank. Concept of sustainability and logistics is discussed in this study focusing on environmental, economic and social dimensions of sustainable logistics.
\end{abstract}

Keywords: Green Logistics, Economy, Sustainability.

\section{SÜRDÜRÜLEBİLIRLİK İÇINN YEŞİL LOJISTİK}

\section{ÖZET}

Sürdürülebilirlik, son yıllarda artan önemiyle göze çarpan bir kavramdır. İşletme faaliyetleri arasında çekirdek bir rolü bulunması dolayısıla, özellikle lojistik sektöründe stratejik bir konu haline gelmiştir. İsletmelerde sürdürülebilirliğin sağlanması; onun çevresel, ekonomik ve sosyal boyutlarının gerçekleştirilmesi ile mümkündür. Bu bağlamda Dünya Bankası tarafindan hazırlanan "Lojistik Performans İndeksi” önemlidir. Bu çallşma da sürdürülebilirlik ve lojistik kavramları sürdürülebilirliğin çevresel, ekonomik ve sosyal boyutları göz önüne alınarak tartışılmıştır.

Anahtar Kelimeler: Yeşil Lojistik, Ekonomi, Sürdürülebilirlik.

* Corresponding Author 


\section{Introduction}

Environmental sustainability, in the academic and industrial senses, has become a subject of great attention in recent years. Intensifying carbon emissions and global warming are demanding substantial efforts by businesses towards ensuring the sustainment of environment. Currently, global competition is forcing a great number of companies and establishments to reduce carbon emission values.

Now businesses will have to face, not only with time and performance constraints, but with the society's points of concern about the environment (Bolat et al, 2011). Because of environmental problems and the worsening scarcity of natural resources, companies must be producing more reliable, healthier products which damage the environment minimally. Starting from that point, companies have been moving forward with a sense of social responsibility and adopting green logistics in order to design cleaner manufacturing processes and manage environmental risks (İnce, 2013). Businesses have been trying to reduce carbon emissions in areas such as finding alternative resources, eliminating packaging, reverse-supply chains and the re-arrangement of distribution channels (Alzaman, 2014).

In this context, green logistics helps improve a business' commercial performance along with its environmental image, and provide for more efficient uses of resources, while also enabling recycling and improving market shares (Yangınlar \& Sarı, 2014). In this study, we aim at establishing the relationship between the concept of sustainability and logistics operations. The concepts of sustainability and logistics are discussed with a focus on environmental, economic and social dimensions of sustainable logistics.

\section{Management of Sustainable Logistics and Green Logistics}

The components of sustainability are economy, environment, society and management, which bind the former three with each other. In other words, the means for achieving sustainability is possible through solutions which treat environment, society and economy together, as a whole. According to the OECD, sustainable development is the meeting the needs of current generations without giving concessions on meeting the needs of future generations (OECD, 2001).

In our days, one of the most important problems faced, in the context of sustainability, is the changing of climate. In fact, in a Green Trend Survey study, as well, the climate change has been shown to be the greatest problem facing the world (Anonymous, 2010:17). The climate change is also considered to an threat to the economy, as well as to the environment. Studies done to the date have shown the climate change to be a result of global warming. According to the Kyoto Protocol, also signed by Turkey, it has been proposed that greenhouse gases' emission be cut down to below 5.2\% (Şişman, 2015). Turkey, on the other hand, is above the world average with its per-capita carbon emission of 6.2 tons (Table 1). This shows that Turkey has to treat the subject of greenhouse gases with greater care. 
Figure 1: Sustainability and Its Components.

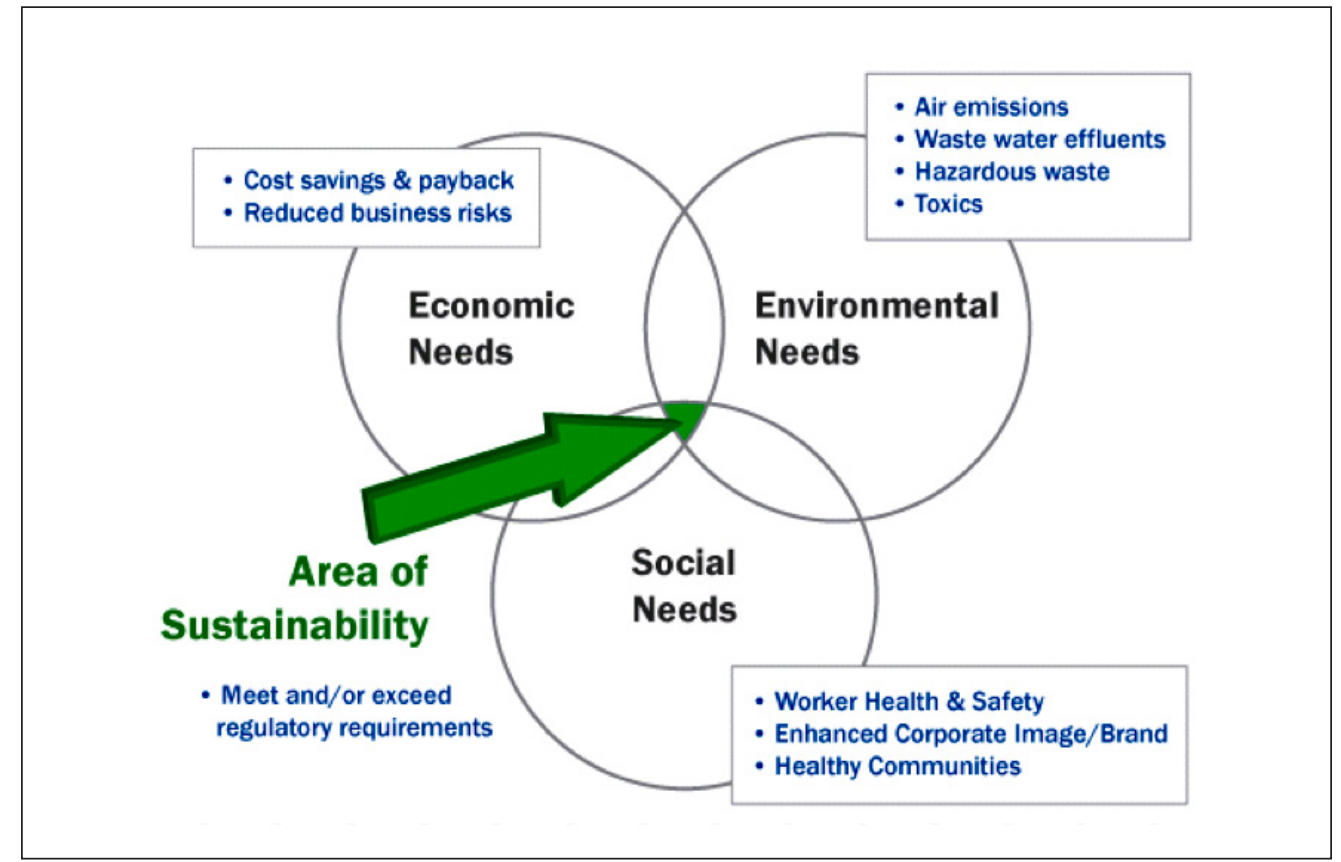

Source: Çamlıca, Z. \& Akar, G.S. (2014). Lojistik sektöründe sürdürülebilirlik uygulamaları. Gümüşhane Üniversitesi Sosyal Bilimler Elektronik Dergisi, 11, 100-119.

Table 1: The Shares of Greenhouse Gases Emissions by the Most-Polluting Five Countries and Turkey

\begin{tabular}{lccc}
\hline & $\begin{array}{c}\text { Greenhouse gas } \\
\text { (CO2 Equivalent, in Million } \\
\text { Metric Tons) }\end{array}$ & $\begin{array}{c}\text { Percentage in } \\
\text { World Total }\end{array}$ & $\begin{array}{c}\text { Per Capita Emission } \\
\text { (CO2 Equivalent in } \\
\text { Metric Tons) }\end{array}$ \\
\hline China & $9,764.7$ & 22.7 & 7.2 \\
\hline U.S.A & $6,854.7$ & 16.0 & 22.0 \\
\hline E.U. 28 & $4,751.1$ & 11.1 & 9.4 \\
\hline India & $2,772.5$ & 6.5 & 2.3 \\
\hline Russia & $2,223.5$ & 5.2 & 6.1 \\
\hline World & $42,968.1$ & 100.0 & 6.2 \\
Total & 411.7 & 0.8 & 6.5 \\
\hline Turkey & & & \\
\hline
\end{tabular}

Source: Yeldan, E. (2015). Paris’te iklim değişikliği mücadelesi. Retrieved November 5, 2016, from http://www. cumhuriyet.com.tr/koseyazisi/445259/Paris_te_iklim_degisikligi_mucadelesi.html. 
The amount of carbon released has been on the increase every passing year. In recent years, certain attempts have been made to reduce these emissions, such as emission trade system, emission deals and carbon taxes. For example, the European Union has made it mandatory that all airlines to buy back $15 \%$ of the carbon emissions that they caused in its airspace through the taxes.

In carbon emissions, which is seen as one of the causes of the climate change, the contribution of logistics sector is about $13.1 \%$. In reducing carbon emissions, the concept of green logistics is becoming prominent in the path leading to sustainability. Logistics is a physical network which connects consumers and the market. Basic functions of logistics consist of five major headings (URL1):

1. Logistics networking

2. Sourcing and procurement

3. Planning and forecasting

4. Transportation

5. Distribution

Logistics operations, on the other hand, can be viewed within two major headings of product and service flows (Tanyaş \& Arıkan, 2013:19), (1) Operations related to product and parcel flow: Transportation, Storage, Packaging and Value-Adding Services, (2) Operations related to service flow: Customs, Insurance, Inspection/Supervision, Stock Management and Order Management.

In addition to product design, raw material preferences, manufacturing of goods, packaging, transportation and recycling, green logistics also encompasses also social and environmental subjects (Linton et.al., 2007; Hazen et al., 2014). Seuring and Müller (2008), defined green logistics as the management of the flow of knowledge, materials and funds between institutions, which aim at growing with emphasis on social and environmental sustainability, while paying attention to the demands of all the stakeholders. Green logistics is a concept which unifies the strategies for product development and environmentally-sensitive methods for manufacturing and service. Through green logistics, the logistics processes are intended to be unburdened of the negative environmental effects of energy, chemicals and emissions (Büyüksaatç1, 2009). Researchers have viewed green logistics from different viewpoints. For example, Zsidisin and Siferd (2001) examined its relation to green purchasing and Rao and Holt (2005) measured its relationship with institutional performance management. Wang and Sarkis (2013) analyzed the relationship between the financial performances of the leading 500 companies and their practices of sustainable logistics management.

The companies which practice green logistics manufacture goods with the minimum energy expenditure, in a way to make them durable and easily recyclable. They also consume less energy during transportation, and do not release more waste than the system can handle. Those companies collaborate with other companies and institutions to achieve these goals. They prefer re-usable containers, pallets and cases, instead of disposable types of packaging. From the point of designing packaging, on to the pollution arising from the use of products by 
consumers, they carefully observe the stages of the processes with care for the environment (Bedük \& Aydın, 2012). In this context, green logistics operations are categorized as in Figure 2:

\section{Green Logistics Operations}

\subsection{Green Purchasing}

Green purchasing is the practice of purchasing goods and services with negative environmental effects in the least possible amounts. When faced with competing choices, it is the preference of materials that are fewer adverse effects on human health and environment. While the choices are compared, a multitude of factors are considered, factors such as the amounts and types of energy and resources used in production of those materials, the cleanliness of manufacturing processes, the means of distribution and whether the utilized resources are replenished. Green purchasing is a launch strategy with a proven success record, which involves purchasing products with recycled contents. In recent years, state establishments and commercial firms have initiated purchasing campaigns leaning towards recycled contents. The growth potential is greater for the firms that purchases recycled goods (Corzine \& Jackson, 2006).

\subsection{Green Production}

According to United Nations Program for the Environment, green production is defined as the implementation of preventative environmental management strategies in a manner integrated in the production process, the elimination of the risks on human health and environmental values and the improvement of efficiency. The idea of producing goods and services with less waste has entered the business world with the name "green production" (Yücel \& Ekmekçiler, 2008). Şişman (2015), in his study, noted that the energy expenditure

Figure 2: Green Logistics Operations

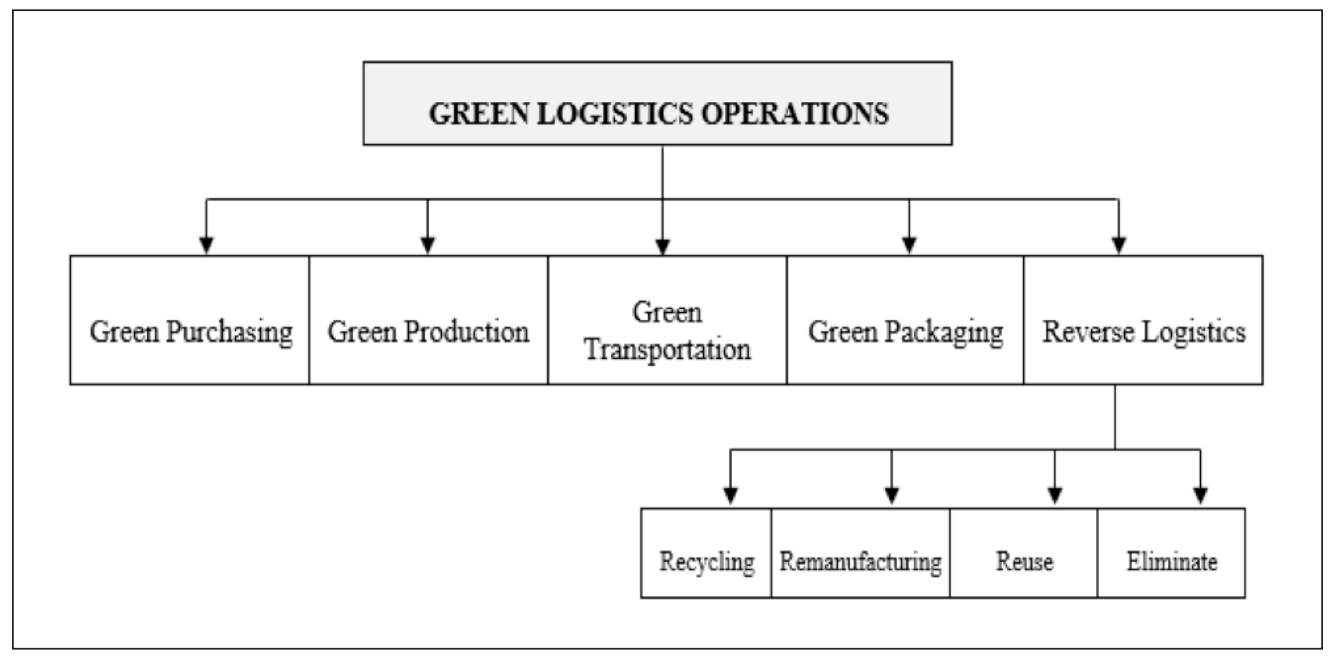

Source: Büyüközkan, G. \& Vardaroğlu, Z. (2008). Yeşil tedarik zinciri yönetimi. Lojistik Dergisi, 8, 66-73. 
of lighting during production is excessive. He stated that placing of artificial light sources correctly and designing production lines in a way to maximally benefit from the daylight will lead to savings in energy.

\subsection{Green Transportation}

Distribution is managing the movements of all the materials in the value chain from the beginning to the end. Business managers responsible from distribution observe the relationship between competitive advantage with the environmental factors. Distribution does have considerable effects on environment. For example, in Britain, exhaust fumes of vehicles are among the important causes of environmental pollution (Ar, 2011). Through green production, the damage to the environment will be brought down to the minimum, while all business costs are being reduced and profits will be increased (Uysal, 2006).

\section{Table 2: Short- and Long-Term Green Distribution Strategies}

Short-Term Distribution Strategies

Environmental supervision must be applied to daily activities

Lifecycle analysis must be utilized to determine the environmental effects of the distribution strategies

Programs must be developed to review and observe the environmental performances of distribution functions

Local groups must be contacted to establish feedback channels about environmental and other social problems

The uses of energy and materials in distribution activities must be accounted

The reasons for ill-performing environmental activities must be focused upon

Environmental criterions and principles must be employed in transportation and general purchasing strategies

A program must be developed for managing the environmentally hazardous materials

High-level educational training programs about environment must be initiated, in a manner that involves developing skills

Long-Term Distribution Strategies

All future activities must utilize environmental effect analyses

Transportation networks must be developed for the awareness of developments

Active plans must be developed to track legal procedures and drivers must be trained and educated to lower maintenance costs

Financial savings must be effected through efficient use of fuel

Relations must be established with internal and external stakeholders

Source: Ar, A. A. (2011). Tekstil sektöründen örneklerle yeşil pazarlama. İstanbul: Beta Yayıncılık. 
The factors affecting green distribution are the fuel used by transporting vehicle, frequency of trips, distance to the clients and other characteristics of hauling, such as materials, shapes and weight (Büyüközkan \& Vardaloğlu, 2008). According to Shang et. al. (2010), the factors affecting green distribution are the recyclableness of packaging or the reusability of containers, the use of materials that are harmless to the environment in packaging and the utilization of environmental management methods (Atrek \& Özdağoğlu, 2014).

Along with the advance of globalization, distances between distribution points are increasing greatly. Longer distances of transportation lead to increased carbon emissions for vehicles. Şişman, in his 2015 study, stated that transportation vehicles are among the most important factors endangering the environment. Highway transportation is in the position of the highest greenhouse gas source, with its $85 \%$ share. The share of emissions from airlines is on the increase. The emissions resulting from railway transportation, on the other hand, are fairly small (UTIKAD, 2012). For example, in Canada, diesel-engine vehicles that make up $4.2 \%$ of all the transportation vehicles cause $29.2 \%$ of emissions. Consequently, businesses choose the types, capacities and other technical specs of vehicles used in transportation in ways to make regional carbon footprints smaller (Elhedhli-Merrick, 2012).

\subsection{Green Packaging}

Green packaging, also known as "ecological packaging" is defined as the method of packaging, which value human and animal health, as well as the environment throughout the lifecycle, using reusable or recycled materials wholly made up of natural plant material. The characteristics of packaging affect performance and efficiency all through the supply chain. For green packaging, attention must be paid to sizes, shapes of the packages and the use of environmentally-friendly materials. The way packaging is done using recycled materials affect the economic performance of a business in a positive manner. Packages manufactured in that manner reduce the use of materials, enable efficient use of space in warehouses and decrease the amount of transportation needed (Büyüközkan \& Vardaloğlu, 2008).

\subsection{Reverse Logistics}

Products, components, materials, equipment and even all the technical system can be re-used in the supply chain (Brito et. al. 2002). Reverse logistics is the recycling of unwanted materials (waste materials, boxes, bottles, papers, etc.) and repurposing them for production, and the utilization of returned or faulty products by sales through different channels (Kaçtığlu \& Şengül, 2010). Stock (2001), on the other hand, defined reverse logistics as "the role of logistics in the reuse of products, reduction of resources, recycling, continuance of and reuse of materials, elimination of waste, fixing and re-manufacturing" (Nakıboğlu, 2007). Reverse logistics is the activity of planning, implementing and controlling the efficient flow of raw materials, semi-completed or final products and the relevant information from the point of consumption to the initial stages, in a manner to ensure adding values and proper disposal (İnce, 2013). Moving from that point, Table 3 shows the components of reverse logistics. 
Table 3: Components of Reverse Logistics

\begin{tabular}{|c|c|c|c|c|c|}
\hline What is it? & Inputs & Activities & Outputs & $\begin{array}{c}\text { From } \\
\text { Where? }\end{array}$ & Where To? \\
\hline $\begin{array}{l}\text { *Processes } \\
\text { *Tasks } \\
\text { *Skills and } \\
\text { activities }\end{array}$ & $\begin{array}{l}\text { *Discarded } \\
\text { goods } \\
\text { *Used products } \\
\text { *Previously } \\
\text { shipped goods or } \\
\text { parts } \\
\text { *Goods or } \\
\text { packages made } \\
\text { of hazardous or } \\
\text { non-hazardous } \\
\text { materials } \\
\text { *Raw materials } \\
\text { *Knowledge } \\
\text { *Within-process } \\
\text { stocks } \\
\text { *Final product }\end{array}$ & $\begin{array}{l}\text { *Planning, } \\
\text { implementing } \\
\text { and controlling } \\
\text { effective and } \\
\text { cost-effective } \\
\text { flow } \\
\text { *Collecting } \\
\text { *Transport } \\
\text { *Storage } \\
\text { *Processing } \\
\text { *Receiving } \\
\text { *Recycling } \\
\text { *Packaging } \\
\text { *Shipping } \\
\text { *Reducing } \\
\text { *Management } \\
\text { *Elimination }\end{array}$ & $\begin{array}{l}\text { *Re-usable } \\
\text { goods } \\
\text { *Recycling } \\
\text { *Re- } \\
\text { manufacturing } \\
\text { *Elimination } \\
\text { *Reducing } \\
\text { *Management } \\
\text { *Return value }\end{array}$ & $\begin{array}{l}\text { *Point of } \\
\text { consumption }\end{array}$ & $\begin{array}{l}\text { *Production } \\
\text { center } \\
\text { *Collection } \\
\text { center } \\
\text { *Point of } \\
\text { origin }\end{array}$ \\
\hline
\end{tabular}

Source: Karaçay, G. (2005). Tersine lojistik: Kavram ve işleyiş. Çukurova Üniversitesi Sosyal Bilimler Enstitüsü Dergisi, 14 (1).

As it is seen in Table 4, in Turkey, highway transportation takes up the greatest share. However, goals have been set to shift modes of transportation from highways to rails and seaways. In that context, Turkey has bound its efforts to battle greenhouse gas emissions to National Climate Change Strategy (2010-2020). In relation to tracking, verifying and reporting of greenhouse gases, a formal procedure has been published about tracking of greenhouse gas emissions. In that respect, the need for making efforts to shift from highway transportation to railway transportation has been emphasized. Through that, there will be less carbon emission.

Table 4: The Current Situation and 2023 Targets of Transportation Shares in Turkey

\begin{tabular}{ccc}
\hline $\begin{array}{c}\text { Transportation Shares Tons-Km } \\
\text { (Domestic Shipping) }\end{array}$ & Current Situation & 2023 Target \\
\hline Highways & $80.63 \%$ & 60 \\
\hline Railways & $4.76 \%$ & 15 \\
\hline Airways & $0.44 \%$ & 1 \\
\hline Seaways & $2.66 \%$ & 10 \\
\hline Pipelines & $11.51 \%$ & 14 \\
\hline
\end{tabular}


Table 4 cont'd

\begin{tabular}{ccc}
\hline $\begin{array}{c}\text { Transportation Shares Passenger-Km } \\
\text { (Domestic Passenger) }\end{array}$ & Current Situation & 2023 Target \\
\hline Highways & $89.59 \%$ & $72 \%$ \\
\hline Railways & 2.22 & $10 \%$ \\
\hline Airways & $7.82 \%$ & $14 \%$ \\
\hline Seaways & $0.37 \%$ & $4 \%$ \\
\hline
\end{tabular}

Source: The Ministry of Transport, Maritime Affairs and Communications (UBAK). (2014). Türkiye kombine taşimacilik strateji belgesi. Retrieved March 5, 2016, from http://www.ubak.gov.tr/BLSM_WIYS/TMKDG/tr/doc/2 0150106_122025_64574_1_64896.pdf.

\section{Applications of Green Logistics}

Applications of green logistics is a subject which gains importance every day. However, in most businesses, green logistics activities are thought to increase costs. In fact, the studies done to date have shown that green logistics applications add to the costs of investment, operations, training and purchasing of environmentally-friendly materials, but reduce the costs of storage, inventory, transportation and energy consumption. In addition, the preference of environmentally-friendly materials improves the institutional images of businesses and lead to consumer satisfaction (Yangınlar \& Sarı, 2014). The basic reasons for businesses switching to green logistics have been listed in Table 5.

\section{Table 5: The Basic Reasons for Businesses Switching to Green Logistics}

1. To manage the effects on the environment by applying original procedures for service and production systems and operations,

2. To improve the qualities and efficiency of services, products, processes and supplies,

3. Enter new markets with certificates received in becoming green,

4. To design products that answer the environmental needs and thus create a difference

4. in products,

5. To alleviate the consumer pressure and make a transition to the preferred-business status,

6. To increase online sales and establish a presence in new distribution channels,

7. To expect the rapid technological developments also in the domain of green technology,

8. Rising costs of energy, increasing scarcity of resources and the interruptions resulting in higher costs,

9. Aging population, increased energy usage due to immigration and the growing importance of energy efficiency projects,

10. Increasing consumer awareness on sustainability and social responsibility.

Source: UTİKAD. (2013). Lojistik firmalarinin yeşil olmasi için 10 temel neden. Retrieved March 5, 2016, from http:// www.utikad.org.tr/haberler/?id=11348. 
In this context, green practices in logistics processes is not limited only to transportation activities, but they also include efficient uses of electricity water and heating in storage facilities, getting a share of energy from renewable sources, designing the facilities in ways to make more use of daylight, installing sensor-operated lighting for less waste, switching from fossil-fuel engines to electric engines for vehicles and the equipment (İpekçi, 2013).

\section{Conclusion}

Currently, competition involves logistics strategies, as well as the products and services they offer in the markets. Consequently, green logistics procedures which aim at realizing business strategies in an environmentally-friendly manner come forward as important points that will provide competitive advantages for businesses.

The operations that will provide social, economic and environmental sustainability closely relate to the logistics sector. Minimizing of the harms that the sector on the environment is only possible through effective strategies for sustainability. In this context, businesses:

- must transport their products in larger bulks.

- must utilize environmentally-friendly and efficient transportation and distribution systems.

- must reduce the packaging operations and the materials used in them.

- must prefer recyclable materials in packaging.

- must train the personnel.

- must inform their clients and consumers.

- must encourage reverse-logistics programs.

- must prefer environmentally-friendly technologies for vehicles/engines.

- must rearrange shipping plans and routes.

- must regularly perform their vehicles' emissions.

- must stop the use of aged vehicles.

\section{References}

Alzaman, C. (2014). Green supply chain modelling: Literature review. International Journal of Business Performance Supply Chain Model, 6(1), 16-39.

Anonymous, (2010). Delivering tomorrow: Towards sustainable logistics. Bonn: Deutsche Post AG.

Ar, A.A. (2011). Tekstil sektöründen örneklerle yeşil pazarlama. İstanbul: Beta Yayıncılık.

Atrek, B. \& Özdağoğlu, A. (2014). Yeşil tedarik zinciri uygulamalari: Alüminyum doğrama sektörü İzmir örneği. Anadolu Üniversitesi Sosyal Bilimler Dergisi, 14(2), 13-25.

Bedük, F. \& Aydın, M.E. (2012, May). Yeşil lojistik uygulamaları. Ulusal Lojistik ve Tedarik Zinciri Kongresi, Konya. 
Bolat, H.B., Bayraktar, D., Öztürk, M. \& Turan, N. (2011, June). Yeşil lojistik zincirinde araç rotalama problemi için bir model önerisi. XI. Üretim Araştırmaları Sempozyumu, İstanbul.

Büyüközkan, G. \& Vardaloğlu, Z. (2008). Yeşil tedarik zinciri yönetimi. Lojistik Dergisi, 8, 66-73.

Büyüksaatçı, S. (2009). Yeşil tedarik zinciri yönetimi ve bir uygulama. Yüksek Lisans Tezi, İstanbul Üniversitesi, İstanbul.

Corzine, J.S. \& Jackson, L.P. (2006). Green purchasing: A guide for local Governments and communities. Athens, 609, 633-1161.

Çamlıca, Z. \& Akar, G.S. (2014). Lojistik sektöründe sürdürülebilirlik uygulamaları. Gümüşhane Üniversitesi Sosyal Bilimler Elektronik Dergisi, 11, 100-119.

Elhedhli, S. \& Merrick, R. (2012). Green supply chain network design to reduce carbon emissions. Transportation Research, 17(5), 370-379.

İnce, M.E. (2013). Yeşil tedarik zinciri yaklaşımı ve örnekleri. Konya Ticaret Odası, Konya.

İpekçi, E. (2013). Lojistikte yeşil çözümler. Retrieved March 25, 2016, from http://www. emreipekci.com/lojistikte-yesil-cozumler.html.

Hazen, B.T., Cegielski, C. \& Hanna, J.B. (2014). Yeşil yayılım tedarik zinciri yönetimi - Yeşil ters lojistik sürecinin algılanan kalitesi üzerine bir çalışma (M.L. Emek, B. Doğan, Çev.). Mukaddime, 5(2), 141-159.

Kaçtıoğlu, S.\& Şengül, Ü. (2010). Erzurum kenti ambalaj atıklarının geri dönüşümü için tersine lojistik ağı tasarımı ve bir karma tamsayılı programlama modeli. Atatürk Üniversitesi Íktisadi ve İdari Bilimler Dergisi, 24(1).

Karaçay, G. (2005). Tersine lojistik: Kavram ve işleyiş. Çukurova Üniversitesi Sosyal Bilimler Enstitüsü Dergisi, 14(1).

Karl, T.R. \& Trenberth, K.E. (2003). Modern global climate change. Science, 302(5651), 17191723.

Linton, J.D., Klassen, R. \& Jayaraman, V. (2007). Sustainable supply chain: An introduction. Journal of Operations Management, 25, 1075-1082.

Marchant, R. (2010). Understanding complexity in savannas: Climate, biodiversity and people, Curr. Opi. Environ. Sustain., 2(1-2), 101-108.

Nakıboğlu, G. (2007). Tersine lojistik: Önemi ve dünyadaki uygulamaları. Íktisadi ve İdari Bilimler Fakültesi Dergisi, 9(2), 1-16.

OECD. (2001, November). Strategies for sustainable development - Practical guidance for development. Paris: OECD.

Rao, P. \& Holt, D. (2005). Do green supply chains lead to competitiveness and economic performance?. International Journal of Operations \& Production Management, 25(9), 898-916.

Seuring, S. \& Müller, M. (2008). From a literature review to a conceptual framework for sustainable supply chain management. Journal of Cleaner Production, 16(15), 16991710. 
Şişman, B. (2015). Sürdürülebilir tedarik zinciri yönetiminde karbon saliniminin sosyal maliyetini dikkate alan bir model önerisi: Bir mermer işletmesi örneği. Niğge Üniversitesi İktisadi ve İdari Bilimler Fakültesi Dergisi, 8(4), 177-193, ISSN: 2148-5801.

Tanyaş, M. \& Arıkan, F. (2013). Bursa ili lojistik merkez ön fizibilite raporu, BUSIAD, Bursa.

UBAK. (2014). Türkiye kombine taşimacilik strateji belgesi. Retrieved March 5, 2016, from http://www.ubak.gov.tr/BLSM_WIYS/TMKDG/tr/doc/20150106_122025_64574_1_6 4896.pdf.

UTIKKAD. (2012). Karbon ayak izi takibine çikan çevre ve şehircilik bakanliği yeşil lojistiğinde önünü açacak. Retrieved January 24, 2016, from http://www.utikad.org.tr/ haberler/?id=9963.

UTIKKAD. (2013). Lojistik firmalarinin yeşil olmasi için 10 temel neden. Retrieved March 5, 2016, from http://www.utikad.org.tr/haberler/?id=11348.

Uysal, O. (2006). Yeşil ürünlerde konumlandırma ile ilgili bir uygulama. Yayımlanmamış Yüksek Lisans Tezi, Marmara Üniversitesi, İstanbul.

Wang, Z. \& Sarkis, J. (2013). Investigating the relationship of sustainable supply chain management with corporate financial performance. International Journal of Productivity and Performance Management, 62(8), 871-888.

Yangınlar, G. \& Sarı, K. (2014, May). Yeşil lojistik uygulamaları ve işletme performansı üzerine bir literatür araştırma. III. Ulusal Lojistik ve Tedarik Zinciri Kongresi, Trabzon.

Yeldan, E. (2015). Paris’te iklim de ğişikliği mücadelesi. Retrieved November 5, 2016, from http://www.cumhuriyet.com.tr/koseyazisi/445259/Paris_te_iklim_degisikligi_ mucadelesi.html.

Yücel, M. \& Ekmekçiler, Ü.S. (2008). Çevre dostu ürün kavramına bütünsel yaklaşım; temiz üretim sistemi, eko-etiket, yeşil pazarlama. Elektronik Sosyal Bilimler Dergisi, 26(26).

Zsidisin, G.A. \& Siferd, S.P. (2001). Environmental purchasing: A framework for theory development. European Journal of Purchasing and Supply Management, 7(1), 61-73.

URL1: Apillioğulları, L. Sürdürülebilirlik. Retrieved March 20, 2016, from http://www. sektorel.com/yazarlar/lutfi-apiliogullari/surdurulebilirlik-sustainability. 